\title{
Analysis of Taxpayers' Non-compliance Factors Based on the Results of the Tax Audit and the Opinion of the Tax Auditor in Indonesia
}

\author{
Anthonius ${ }^{1}$, Muhammad Nuryatno Amin² \\ \{anthony_partners@yahoo.com ${ }^{1}$ \} \\ ${ }^{1}$ Universitas Kristen Maranatha, Bandung, Indonesia \\ ${ }^{2}$ Universitas Trisakti, Jakarta, Indonesia
}

\begin{abstract}
One cause which makes tax revenue in Indonesia is not yet optimal because the lack of compliance of the taxpayer to fulfill their tax obligation. Tax compliance is a problem which happened in almost all country applying taxation system. The result of the tax audit is one of the media which can be used to evaluate the tax compliance of the taxpayer. This research describes the factor that causes the non-compliance of the taxpayer in Indonesia based on the correction in tax audit report and the opinion of the tax auditor. This research shows the analysis and auditor's point of view and tax auditor report, which is different from the research with taxpayer sample. This research uses qualitative methods. The sample of this research uses a tax audit report based on the tax inspection on 2013-2015. An interview and questionnaire filling methods are conducted for 30 tax auditors. This research shows the analysis of non-compliance tax factor based on the result of tax audit and tax auditor opinion. One factor that causes the noncompliance of the taxpayer is they do not understand the tax rules.
\end{abstract}

Keyword: Tax audit report, Tax non-compliance, Tax regulations, Indonesia

\section{Introduction}

Tax is a source of state revenue that is used for government expenditure and development needs. The contribution of tax revenue in Indonesia since 2012-2016 is significant, reaching more than $79 \%$ of total state revenues. The government is trying to optimize tax revenue. However, the tax revenue in Indonesia is not yet optimal because the low level of taxpayer's compliance in fulfilling their tax obligations. Tax compliance issues occur in almost all countries that implement the tax system (Kirchler, 2008; Alm and McClellan, 2012). Every year the government strives to maximize tax revenue to develop the nation better, and to improve the welfare of the community (Simanjuntak and Mukhlis, 2011).

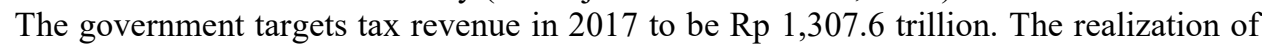
tax revenue in that year can be achieved by increasing taxpayer's compliance. Until the end of August 2017, the realization of new tax revenues reached $\mathrm{Rp} 686.5$ trillion (Directorate General of Tax, 2017). Therefore, the government has undertaken various efforts to improve the compliance with mandatory taxes in 2016 and 2017. One of the efforts is by providing tax amnesty starting on July 1, 2016, and ending on March 31, 2017. Indonesia is considered successful in implementing and achieving the desired target through Tax Amnesty. Beside many new taxpayers are registered, there are some old taxpayers correcting the reports, declaring existed assets which have not been reported, and depositing existed tax deficiencies.

Tax compliance issues and various research on tax compliance in Indonesia can be used as a reference for seeing and handling taxation problems in Indonesia; compliance issues can be seen in terms of law enforcement, public finance, labor, organizational structure, or ethics 
(Hallsworth et al. 2017; Murphy 2008; Cummings et al. 2009; Andreoni, Erard, and Feinstein, 1998).

Law enforcement through tax audit procedures in the case of law enforcement carried out by the Directorate General of Taxes, Ministry of Finance of the Republic of Indonesia, which consists of series of activities in collecting and processing data. The information and evidence are carried out objectively and professionally based on an inspection standard, in order to test the compliance of tax obligations in the framework of implementing the provisions of the taxation legislation. The purpose of tax audit is to examine the compliance with tax obligations, which is related to the notification of the Tax Return, not too late or beyond the stipulated period, and has fulfilled the provisions of tax laws and regulations (Directorate General of Taxes, 2012).

The result of tax audit is a document that can be used to assess taxpayer's compliance. The results of tax audit can provide information about the reasons for the correction of tax report, the legal basis, and the taxpayer's opinion on the correction. Correction is the amount of the difference between the tax reports of reported taxpayer with the results of tax auditors' calculations (Dubin and Wild, 1988). The size of correction in the tax audit results can be seen as a benchmark for the level of taxpayer's compliance, although this correction does not necessarily imply non-compliance with taxpayer (Gallagher, 2005).

Based on the correction, it can be analyzed that whether the taxpayer does not understand the tax regulations, the taxpayer is wrong in applying tax laws, the elements of negligence, the taxpayer's intention to reduce the value of tax reporting, or because there is a different opinion between tax auditor with taxpayer related to financial transactions and tax regulations.

The studies about tax compliance from the perspective of taxpayer are still rarely research in Indonesia. Therefore, this study try to fill the gap by identifying that tax compliance take the perspective of tax audit report and the opinion of auditors who conduct an audit of taxes.

This study describes the factors causing the non-compliance of taxpayer in Indonesia based on the corrections in tax audit reports and the opinions of the auditors who conduct tax audits. The implications of this study provide valuable insights to various parties related to tax in Indonesia, especially to the tax authorities in Indonesia (Directorate General of Taxes). This research is also expected to give a contribution to researchers in other countries, especially in Asia, given that tax disobedience is a common and universal problem.

Related to tax non-compliance, the result of the research proves that the factors influencing tax revenue are taxpayer's compliance, an increase of non-taxable income, tax audit, and sunset policy (Bikas and Andruskaite, 2013; Merrifield, 2000; von Haldenwang et al. 2013; Wulandari, 2015). In this case, it can be said that tax compliance is an important source to increase tax revenue (Kirchler and Wahl, 2010; Cullis, Jones and Savoia, 2012). Related to tax compliance itself, the research finds that the most factors influencing taxpayer's compliance in carrying out their tax obligations is the use of sanctions against the taxpayer who does not perform their obligations in accordance with applicable legislation (Hallsworth, 2014; Mohdali and Pope, 2014; Saad, 2014; Tantio Dharma and Ariyanto, 2014; Jimenez and Iyer, 2016).

Tax compliance defines as filing all requested tax returns on time, and then reported it to accurately tax liable in accordance with the tax code, regulations, and court decisions that is applied at the time the refund is filed (Roth, Scholz and Witte, 1989). Previous research has been done on tax non-compliance from taxpayer's point of view, while the samples were taken from taxable entrepreneurs (Kirchler, 2008; Cullis, Jones and Savoia, 2012; Mohdali and Pope, 2014; Saad, 2014). The results of the study indicate that there are five factors 
influencing the non-compliance of taxpayer in paying value-added tax. These factors are the factors of trust in legal certainty, taxpayer's perception factors on value-added tax sanctions, factors of the company's economic condition, mass media and political factors, and valueadded tax awareness factors (Baube, 2011; Effendy and Toly, 2013).

Various studies on tax non-compliance in Indonesia provide a description about the awareness of paying taxes, knowledge, and understanding tax regulations, tax services; tax sanctions affect the compliance of a taxpayer (Andinata, 2014; Dharma and Ariyanto, 2014). Other factors such as individual characteristics will be reflected in attitudes, subjective norms, moral obligations, knowledge of taxes, intentions, and non-tax compliance which are closely linked to existing taxation in Indonesia. Other studies indicate that subjective norms have a powerful influence on non-compliance of taxpayer (Hite, 1997; Murphy, 2005; Jayanto, 2011; Wanarta and Mangoting, 2014). Perception of justice from the tax system and moral norms as well as previous research literature shows that there is a significant effect on the intention to behave non-compliant in taxation in Indonesia (Kelly, 1993; Damayanti, 2012; Basri and Surya, 2014).

The knowledge of taxpayer has a significant effect on taxpayer's compliance, while taxpayer awareness does not significantly affect taxpayer's compliance. Other factors such as increased knowledge of taxation will lead to higher taxpayer's intention to submit timely notification letters. (Eriksen and Fallan, 1996; Mei Tan and Chin - Fatt, 2000; Hofmann, Hoelzl and Kirchler, 2008). The assertiveness of tax sanctions and tax amnesty regulations also has a positive effect on taxpayer's compliance behavior (Saraçoğlu and Çaşkurlu, 2011; Bose and Jetter, 2012; NAR, 2015; Rahayu, 2017).

There are various studies on tax non-compliance outside Indonesia, especially in developing countries that are quite equal to Indonesia(Oh Teik and Lim Meng, 2011; Rani et al., 2013; Azrina Mohd Yusof, Ming Ling and Bee Wah, 2014; Mohdali, Isa and Yusoff, 2014). One of the studies is the study which identifies the factors influencing the behavior of non-tax compliance among Small and Medium Enterprises in Malaysia. The study analyzes the companies which have been audited and investigated by Inland Revenue Board of Malaysia, and showing the marginal tax rates had a more significant impact on noncompliance behaviors. They found that the ownership level of directors, the efficiency level, the size, and the difference of book-tax are the key factors that influence the behavior of corporate tax incompetence. (Mohd Nor, Ahmad and Mohd Saleh, 2010). The effectiveness of the government, the transparent taxation system, and accountability are considered as the basis for improving tax compliance (Nkundabanyanga et al., 2017). In addition, marginal tax rates, firm size, and industry types have a significant impact on tax non-tax compliance (Nkundabanyanga et al., 2017).

\section{Research Methodology}

This study used qualitative research methods. This study is a descriptive research and uses analysis. Theoretical basis, literature review, and previous research are used to assist researchers in analyzing facts in the field and to provide an overview of the background of the study and analyze the discussion of research results. Furthermore, this study aims to explain phenomena in depth through data collection. The research sample in this study is a tax audit report based on a tax audit for the 2013-2015 periods. The data are obtained from tax consultants in Indonesia. Besides, the researchers also conducted interviews and filled out an open questionnaire to 30 tax auditors. Through this method, the data are analyzed using the data obtained from tax audit reports and the results of interviews with auditors. 


\section{Research And Discussion}

The study limits the analysis of the tax audit report from the period of 2013-2015 and interviews with 30 auditors examining various tax cases in Indonesia. The study only analyzes the related cases concerning Income Tax Article 21, Income Tax Article 23, Article 4 paragraph 2, Article 44 paragraph (1) of the Income Tax Law, and other Cases related to Article 6 of the Income Tax Law and Article 9 of the Income Tax Law.

A tax audit is a series of activities in collecting and processing data, information, and evidence that is implemented objectively and professionally based on a standard examination to test compliance with tax obligations to implement the provisions of the taxation legislation.

The result of tax audit is a document that can be used to assess taxpayer's compliance. The results of tax audit can provide information about the reasons for the correction of tax report, the legal basis and the opinion of taxpayer on correction. Correction is the amount of the difference between tax reports reported taxpayer with the results of calculations of tax auditors.

The size of correction in tax audit results can be seen as a benchmark for the level of taxpayer's compliance, although this correction does not necessarily imply non-compliance with taxpayer.

The analysis of non-compliance factors based on the tax audit result and based on the opinion of the tax auditor can be grouped based on the scope of the examination (per type of tax performed by inspection).

According to the Regulation of the Director General of Tax No.PER-32 / PJ / 2015 on Income Tax Article 21, the definition of Income Tax 21 is tax on income in the form of salary, wages, honoraria, allowances, and other payments by name, in whatever form in respect of employment or occupation, services, and activities performed by individual domestic tax subjects. Cases of tax audit on the object of Income Tax Article 21, the correction is made because there is an object of Income Tax Article 21 which has not been subject to tax deduction and reporting. The legal basis on which the correction based is Article 21 of the Income Tax Law. Firstly, the cause of correction among others arises as a result of the difference between the burdens of the salary cost in the general ledger with the object of Income Tax Article 21 reported in the Periodic Tax Return. Secondly, there is a benefit to the employee which is the object of Income Tax Article 21 that has not been subject to tax withholding. It is in the opinion of the auditor which occurs because at the time of examination made, the taxpayer cannot provide documents/evidence related to Article 21 income tax deductions done, or due to taxpayer's incompetence related expenses which are objects of Income Tax Article 21.

Income Tax (Income Tax) Article 23 is a tax withheld on income derived from capital, delivery of services, or prizes and awards, other than that withheld by Income Tax Article 21. Cases of tax audit of the object of Article 23, the correction is done because there is the object of Article Income 23 which has not been subject to tax deductions and tax reporting by taxpayer. The cause of the correction is that there is a difference between the imposition of fees in connection with the services in the ledger and the object of Income Tax Article 23 reported in Periodic Tax Return. It is in the opinion of the auditor which occurs because at the time of the examination is made the taxpayer cannot provide documents/evidence related to Article 23 of income tax deductions, or due to taxpayer's incompetence related expenses which are objects of Income Tax Article 23.

Income Tax Article 4 paragraph 2 or also referred to as final Income Tax is the tax imposed on corporate taxpayer and personal taxpayer for certain types of income they receive 
and the tax deduction is final. This Income Tax Article 4 Paragraph 2 tariff varies for each type of income. Tax audit cases on the object of Income Tax Article 4 paragraph (2), the correction is done because there is an object of Income Tax Article 4 (2) that has not been deducted and tax reporting by the taxpayer, where the cause of correction is the difference between charging rental fees in ledgers and Income Tax objects Article 4 paragraph (2) reported in the Periodic Tax Return. For the taxpayer who is categorized as Micro, Small and Medium Enterprises, calculating their taxes based on net business circulation after deducting operational costs and others, so as not to provide a clear picture of the actual amount of business taxpayer's turnover in the current year. It is in the opinion of the auditor which occurs because at the time of the inspection the taxpayer is unable to provide documents/evidence related to the deduction of Income Tax Article 4 (2), or because of the taxpayers' incomprehension regarding the objects of Article 4 (2).

Examination cases that are more complex and require a more in-depth audit process are mainly carried out in the examination of corporate taxpayer (corporate income tax). Based on the results of the examination related to Article 4 paragraph (1) of the Income Tax Act, income is often found in a checking account, ledger or other sources that the taxpayer has not reported as income. Whether it is intentionally hiding income that should be taxed, or under the pretext of the taxpayer stating that it is not an additional income for his company, referring to the contents and explanation of this Income Tax Article 4 paragraph (1), without the addition of the number of shares.

Other cases related to Article 6 and Article 9 of the Income Tax Law. In Income Tax, known as taxable-deductible and nontaxable-nondeductible, that is, if an income can be taxed for the recipient, then the income can be charged as a cost by the issuing party. If an income cannot be taxed for the party who receives it, then the expenditure on that income cannot be charged as a cost by the issuing party.

Based on the results of the examination, costs that cannot be charged are often found because they are not in accordance with the actual evidence and transaction. In this case, there is a cost data after examination which shows that there is no evidence of a transaction. The auditors argue that taxpayer make an intentional element by charging fees that are not based on actual transactions, or some fees that cannot be charged. Some costs should not be charged by the taxpayer because the right to impose the taxpayer is on other taxpayers, the opinion of the auditor, in this case, is that there are differences of opinion about the transaction material. Therefore, the costs that can be charged are the costs associated with spending to obtain, collect, and maintain income.

This research can provide a comparison with previous studies which emphasize more on the taxpayer's point of view of compliance (Mason and Mason, 1992; Fauvelle-Aymar, 1999; Kasper, Kogler and Kirchler, 2015). For instance, the perception of taxpayer on value-added tax sanctions, factors of the company's economic conditions, mass media and political factors, and awareness factors Value added tax is a factor in tax compliance in Indonesia (Effendy and Toly, 2013). The results of the study are based on the results of the tax audit and the opinion of the tax auditor; the factors that lead to non-compliance of taxpayer in the examination process are. For instance, due to taxpayer's misunderstanding of tax regulations, especially regarding tax objects, Income Tax Article 21, Article 23, and Article 4 (2). It is in line with research related to the research of Andinata (2014), Dharma and Ariyanto (2014) which shows that taxation regulations affects compliance with paying taxes. Like two sides of a coin, it can be said that one of the factors of tax compliance is seen from both sides of the view, namely from research on taxpayer and from tax audit reports and interviews with auditors, 
understanding factors and perceptions of tax regulations in Indonesia are one of the factors of tax disobedience in Indonesia.

In contrast to the research that takes the viewpoint and the sample of taxpayer, that say the subjective norm factor becomes one of the many factors inferred in the non-tax compliance (Alm, McClelland and Schulze, 1999; Wenzel, 2004; Jayanto, 2011; Morse, 2011; Wanarta and Mangoting, 2014), the results of research that takes the viewpoint of the tax audit report, not many analysis reports from the auditors who say that the number of tax cases that occur due to the subjective norm factor.

Various studies that take the sample of the taxpayer provide many research results and various factors related to non-tax compliance in Indonesia (Jayanto, 2011; Simanjuntak and Mukhlis, 2011; Effendy and Toly, 2013; Andinata, 2014; Basri and Surya, 2014; Dharma and Ariyanto, 2014; Tantio Dharma and Ariyanto, 2014; Wanarta and Mangoting, 2014; Wulandari, 2015; Rahayu, 2017). However, based on the results of research and review tax audit reports in Indonesia, and also the interviews with tax auditors, it can be seen that the findings are not entirely in line with research that takes the samples from taxpayer and gap occurs in that regard.

Research on tax compliance should not only take the point of view and sample only from the taxpayer, but another point of view from the tax auditor and tax audit report is also needed to dig deeper the factors of tax compliance in Indonesia.

Future research is expected to increase the sample of auditors, and to analyze other than cases concerning Article 21, Article 23, Article 4 paragraph 2, Article 4 paragraph (1), Article 6 , and Article 9 Income Tax contained in the tax audit report in Indonesia.

\section{Research Conclusion}

Based on the results of the tax audit and the opinion of the tax auditor, the factors that cause taxpayer's non-compliance in the audit process are taxpayer's misunderstanding of tax regulations, especially regarding tax objects, either Article 21, Article 23, and Article 4 (2) Income Tax. Furthermore, the taxpayer misunderstood about the tax regulations, especially on costs that can be charged or that cannot be charged as a deduction from taxable income according to Article 6 of the Income Tax Law and Article 9 of the Income Tax Law. Documents/supporting evidence of transactions that taxpayer cannot provide in the inspection process. Without the document/evidence supporting the transaction, the taxpayer's opinion in response to the examination cannot be ascertained. Valid evidence is required in the tax audit process. There are differences of opinion about the transaction material, and there are differences in the interpretation of the provisions of the Law relating to transactions with parties that have a special relationship. Differences in the interpretation of the provisions of the Law are not limited to transactions with parties that have a special relationship but also to other regulations. The differences in interpretation of the provisions of the Act are possible because there are provisions that can interpret differently, the term a gray area. These provisions require revisions and improvements through technical instructions to eliminate multiple interpretations. It was found that there is an intention of the taxpayer to deliberately hide the income that should have been taxed, or intentionally charging fees for which the real transaction did not occur. If it can be proven that there is an intentional element committed by the taxpayer, then not only tax sanctions but also criminal penalties can be imposed on the taxpayer. 


\section{References}

[1] Alm, J. and McClellan, C. (2012) 'Tax Morale and Tax Compliance from the Firm's Perspective', Kyklos. John Wiley \& Sons, Ltd (10.1111), 65(1), pp. 1-17. doi: 10.1111/j.1467-6435.2011.00524.x.

[2] Alm, J., McClelland, G. H. and Schulze, W. D. (1999) 'Changing the Social Norm of Tax Compliance by Voting', Kyklos. John Wiley \& Sons, Ltd (10.1111), 52(2), pp. 141-171. doi: 10.1111/j.1467-6435.1999.tb01440.x.

[3] Andinata, M. C. (2014) 'Analisis Faktor-Faktor yang Mempengaruhi Kepatuhan Wajib Pajak Orang Pribadi dalam Membayar Pajak: Studi Kasus Pada Kantor Pelayanan Pajak Pratama surabaya Rungkut di Surabaya'. UNKNOWN. Available at: http://repository.ubaya.ac.id/25306/ (Accessed: 27 December 2018).

[4] Andreoni, J., Erard, B. and Feinstein, J. (no date) 'Tax Compliance', Journal of Economic Literature. American Economic Association, pp. 818-860. doi: $10.2307 / 2565123$.

[5] Azrina Mohd Yusof, N., Ming Ling, L. and Bee Wah, Y. (2014) 'Tax non-compliance among SMCs in Malaysia: tax audit evidence', Journal of Applied Accounting Research. Emerald Group Publishing Limited , 15(2), pp. 215-234. doi: 10.1108/JAAR-02-2013-0016.

[6] Basri, Y. . and Surya, R. A. . (2014) 'Pengaruh keadilan, norma ekspektasi, sanksi dan religiusitas terhadap niat dan ketidak patuhan pajak', Akuntabilitas, VII(3), pp. 162 176.

[7] Baube, L. (2011) 'Tax Compliance1', Journal of Accounting and Taxation, 5(3), pp. 48-57.

[8] Bikas, E. and Andruskaite, E. (2013) 'FACTORS AFFECTING VALUE ADDED TAX REVENUE', European Scientific Journal, ESJ, 9(19). doi: 10.19044/esj.2013.v9n19p\%p.

[9] Bose, P. and Jetter, M. (2012) 'Liberalization and tax amnesty in a developing economy', Economic Modelling. North-Holland, 29(3), pp. 761-765. doi: 10.1016/J.ECONMOD.2012.01.017.

[10] Cullis, J., Jones, P. and Savoia, A. (2012) 'Social norms and tax compliance: Framing the decision to pay tax', The Journal of Socio-Economics. North-Holland, 41(2), pp. 159-168. doi: 10.1016/J.SOCEC.2011.12.003.

[11] Cummings, R. G. et al. (2009) 'Tax morale affects tax compliance: Evidence from surveys and an artefactual field experiment', Journal of Economic Behavior \& Organization. North-Holland, 70(3), pp. 447-457. doi: 10.1016/J.JEBO.2008.02.010.

[12] Damayanti, T. W. (2012) 'Changes on Indonesia Tax Culture, Is There a Way? Studies Through Theory of Planned Behavior', Journal of Arts, Science \& Commerce, 4(4), pp. 8-16.

[13] Dharma, M. T. and Ariyanto, S. (2014) 'Analisis Faktor-Faktor Yang Memengaruhi Tingkat Kepatuhan Wajib Pajak Orang Pribadi Di Lingkungan Kantor Pelayanan Pajak Pratama, Tigaraksa Tangerang', Binus Bussines Review, 5(4468557), pp. 497-509. doi: 446855.

[14] Dubin, J. A. and Wilde, L. L. (no date) 'An Empirical Analysis Of Federal Income Tax Auditing And Compliance', National Tax Journal. National Tax Association, pp. 6174. doi: $10.2307 / 41788709$.

[15] Effendy, T. S. and Toly, A. A. (2013) 'Faktor-Faktor yang Mempengaruhi Ketidakpatuhan Wajib Pajak dalam Membayar Pajak Pertambahan Nilai', Petra 
Christian University Tax and Accounting Review. Universitas Kristen Petra, 1(1). Available at: https://www.neliti.com/id/publications/193011/faktor-faktor-yangmempengaruhi-ketidakpatuhan-wajib-pajak-dalam-membayar-pajak (Accessed: 27 December 2018).

[16] Eriksen, K. and Fallan, L. (1996) 'Tax knowledge and attitudes towards taxation; A report on a quasi-experiment', Journal of Economic Psychology. North-Holland, 17(3), pp. 387-402. doi: 10.1016/0167-4870(96)00015-3.

[17] Fauvelle-Aymar, C. (1999) 'The Political and Tax Capacity of Government in Developing Countries', Kyklos. John Wiley \& Sons, Ltd (10.1111), 52(3), pp. 391-413. doi: 10.1111/j.1467-6435.1999.tb00224.x.

[18] Gallagher, M. (2005) 'Benchmarking tax systems', Public Administration and Development. John Wiley \& Sons, Ltd, 25(2), pp. 125-144. doi: 10.1002/pad.353.

[19] von Haldenwang, C. et al. (2013) 'Study on the Vulnerability and Resilience Factors of Tax Revenues in Developing Countries. Study funded by the European Commission', SSRN Electronic Journal. doi: 10.2139/ssrn.2366285.

[20] Hallsworth, M. (2014) 'The use of field experiments to increase tax compliance', Oxford Review of Economic Policy. Oxford University Press, 30(4), pp. 658-679. doi: 10.1093/oxrep/gru034.

[21] Hallsworth, M. et al. (2017) 'The behavioralist as tax collector: Using natural field experiments to enhance tax compliance', Journal of Public Economics. North-Holland, 148, pp. 14-31. doi: 10.1016/J.JPUBECO.2017.02.003.

[22] Hite, P. A. (1997) 'Identifying and Mitigating Taxpayer Non-Compliance', Australian Tax Forum, 13. Available at: https://heinonline.org/HOL/Page?handle=hein.journals/austraxrum13\&id=159\&div=\& collection $=$ (Accessed: 27 December 2018).

[23] Hofmann, E., Hoelzl, E. and Kirchler, E. (2008) 'Preconditions of Voluntary Tax Compliance', Zeitschrift für Psychologie / Journal of Psychology. Hogrefe \& Huber Publishers , 216(4), pp. 209-217. doi: 10.1027/0044-3409.216.4.209.

[24] Jayanto, P. Y. (2011) 'Faktor-Faktor Ketidakpatuhan Wajib Pajak', Jurnal Dinamika Manajemen, 2(1). doi: 10.15294/jdm.v2i1.2487.

[25] Jimenez, P. and Iyer, G. S. (2016) 'Tax compliance in a social setting: The influence of social norms, trust in government, and perceived fairness on taxpayer compliance', Advances in Accounting. Elsevier, 34, pp. 17-26. doi: 10.1016/J.ADIAC.2016.07.001.

[26] Kasper, M., Kogler, C. and Kirchler, E. (2015) 'Tax policy and the news: An empirical analysis of taxpayers' perceptions of tax-related media coverage and its impact on tax compliance', Journal of Behavioral and Experimental Economics. North-Holland, 54, pp. 58-63. doi: 10.1016/J.SOCEC.2014.11.001.

[27] Kelly, R. (1993) 'Property Tax Reform in Indonesia: Applying A Collection-Led Implementation Strategy', Bulletin of Indonesian Economic Studies, 29(1), pp. 85-104. doi: 10.1080/00074919312331336351.

[28] Kirchler, E. (2008) 'Why paying taxes? A review of tax compliance decisions', International Journal of Psychology, 43(3-4), pp. 200-201.

[29] Kirchler, E. and Wahl, I. (2010) 'Tax compliance inventory TAX-I: Designing an inventory for surveys of tax compliance', Journal of Economic Psychology. NorthHolland, 31(3), pp. 331-346. doi: 10.1016/J.JOEP.2010.01.002.

[30] Mason, L. and Mason, R. (1992) 'A Moral Appeal for Taxpayer Compliance: The Case for a Mass Media Campaign', Law \& Policy. John Wiley \& Sons, Ltd (10.1111), 14(4), pp. 381-399. doi: 10.1111/j.1467-9930.1992.tb00090.x. 
[31] Mei Tan, L. and Chin - Fatt, C. (2000) 'The Impact of Tax Knowledge on the Perceptions of Tax Fairness and Attitudes Towards Compliance', Asian Review of Accounting. MCB UP Ltd, 8(1), pp. 44-58. doi: 10.1108/eb060720.

[32] Merrifield, J. (2000) 'State Government Expenditure Determinants and Tax Revenue Determinants Revisited', Public Choice. Kluwer Academic Publishers, 102(1/2), pp. 25-48. doi: 10.1023/A:1005036918713.

[33] Mohd Nor, J., Ahmad, N. and Mohd Saleh, N. (2010) 'Fraudulent financial reporting and company characteristics: tax audit evidence', Journal of Financial Reporting and Accounting. Emerald Group Publishing Limited, 8(2), pp. 128-142. doi: 10.1108/19852511011088389.

[34] Mohdali, R., Isa, K. and Yusoff, S. H. (2014) 'The Impact of Threat of Punishment on Tax Compliance and Non-compliance Attitudes in Malaysia', Procedia - Social and Behavioral Sciences. Elsevier, 164, pp. 291-297. doi: 10.1016/J.SBSPRO.2014.11.079.

[35] Mohdali, R. and Pope, J. (2014) 'The influence of religiosity on taxpayers' compliance attitudes', Accounting Research Journal. Edited by A. Prof. Brett Freudenberg, Prof Kerri. Emerald Group Publishing Limited , 27(1), pp. 71-91. doi: 10.1108/ARJ-082013-0061.

[36] Morse, S. C. (2011) 'Tax Compliance and Norm Formation under High-Penalty Regimes', Connecticut Law Review, 44. Available at: https://heinonline.org/HOL/Page?handle=hein.journals/conlr44\&id=681\&div=\&collect ion= (Accessed: 27 December 2018).

[37] Murphy, K. (2005) 'Regulating More Effectively: The Relationship between Procedural Justice, Legitimacy, and Tax Non-compliance', Journal of Law and Society. John Wiley \& Sons, Ltd (10.1111), 32(4), pp. 562-589. doi: 10.1111/j.14676478.2005.00338.x.

[38] Murphy, K. (2008) 'Enforcing Tax Compliance: To Punish or Persuade?', Economic Analysis and Policy. Elsevier, 38(1), pp. 113-135. doi: 10.1016/S0313-5926(08)500099.

[39] NAR, M. (2015) International journal of economics and financial issues., International Journal of Economics and Financial Issues. EconJournals. Available at: http://econjournals.com/index.php/ijefi/article/view/1044 (Accessed: 27 December 2018).

[40] Nkundabanyanga, S. K. et al. (2017) 'Tax compliance in a developing country', Journal of Economic Studies. Emerald Publishing Limited , 44(6), pp. 931-957. doi: 10.1108/JES-03-2016-0061.

[41] Oh Teik, H. and Lim Meng, S. (2011) 'Behavioral intention of tax non-compliance among sole- proprietors in Malaysia', International Journal of Business and Social Science, 2(6), pp. 142-152.

[42] Rahayu, N. (2017) 'Pengaruh Pengetahuan Perpajakan, Ketegasan Sanksi Pajak, Dan Tax Amnesty Terhadap Kepatuhan Wajib Pajak', Akuntansi Dewantara, 1(1), pp. 1530. doi: 10.29230/AD.V1I1.21.

[43] Rani, U. et al. (2013) 'Minimum wage coverage and compliance in developing countries', International Labour Review. John Wiley \& Sons, Ltd (10.1111), 152(3-4), pp. 381-410. doi: 10.1111/j.1564-913X.2013.00197.x.

[44] Roth, J. A., Scholz, J. T. and Witte, A. D. (1989) Taxpayer compliance. University of Pennsylvania Press.

[45] Saad, N. (2014) 'Tax Knowledge, Tax Complexity and Tax Compliance: Taxpayers' View’, Procedia - Social and Behavioral Sciences. Elsevier B.V., 109(1), pp. 1069 
1075. doi: 10.1016/j.sbspro.2013.12.590.

[46] Saraçoğlu, O. F. and Çaşkurlu, E. (2011) 'Tax Amnesty with Effects and Effecting Aspects: Tax Compliance, Tax Audits and Enforcements Around; The Turkish Case', International Journal of Business and Social Science, 2(7), pp. 95-103. doi: Doi 10.3866/Pku.Whxb201304222.

[47] Simanjuntak, T. H. and Mukhlis, I. (2011) 'Pentingnya Kepatuhan Pajak dalam Meningkatkan Kesejahteraan Hidup Masyarakat'. Available at: https://repository.maranatha.edu/88/ (Accessed: 27 December 2018).

[48] Tantio Dharma, M. and Ariyanto, S. (2014) 'Analisis Faktor-Faktor yang Memengaruhi Tingkat Kepatuhan Wajib Pajak Orang Pribadi di Lingkungan Kantor Pelayanan Pajak Pratama, Tigaraksa Tangerang', Binus Business Review, 5(2), p. 497. doi: $10.21512 /$ bbr.v5i2.1008.

[49] Wanarta, F. E. and Mangoting, Y. (2014) 'Pengaruh Sikap Ketidakpatuhan Pajak, Norma Subjektif, dan Kontrol Perilaku yang Dipersepsikan terhadap Niat Wajib Pajak Orang Pribadi untuk Melakukan Penggelapan Pajak', Tax \& Accounting Review, 4(1), p. 138. Available at: http://publication.petra.ac.id/index.php/akuntansipajak/article/view/3112 (Accessed: 27 December 2018).

[50] Wenzel, M. (2004) 'An analysis of norm processes in tax compliance', Journal of Economic Psychology. North-Holland, 25(2), pp. 213-228. doi: 10.1016/S01674870(02)00168-X.

[51] Wulandari, R. (2015) 'Faktor-Faktor Yang Mempengaruhi Penerimaan Pajak Penghasilan Pada Kpp Pratama', Perbanas Review, 1(01). Available at: http://jurnal.perbanas.id/index.php/JPR/article/view/11 (Accessed: 27 December 2018).

[52] _.2012.Tax checks.Directorate General of Taxation, Ministry of Finance. http://www.pajak.go.id/content/pemeriksaan-pajak, accessed 10 November 2017.

[53] 2013. The Income Tax Law and its implementing regulations.

[54] $\overline{\mathrm{http}}: / /$ www.pajak.go.id/sites/default/files/UU-PPh-001-13-UU\%20PPh\%20201300\%20Mobile.pdf, accessed November 10, 2017. 